\title{
Peran Interaksi Simbolik dalam Perencanaan Komunikasi Pemasaran Digital (Studi Kasus pada Instagram @ digitalsuplaiindonesia)
}

\author{
Eric Gautama1, Muhammad Adi Pribadi* \\ ${ }^{1}$ Fakultas Ilmu Komunikasi, Universitas Tarumanagara, Jakarta \\ Email:ericgautama98@gmail.com \\ ${ }^{2}$ Fakultas Ilmu Komunikasi, Universitas Tarumanagara, Jakarta* \\ Email:adip@fikom.untar.ac.id
}

\begin{abstract}
The development of the digital industry in the last decade has led to business actors being carried away by digitalization in all fields of business, from food, tourism, transportation, to even services. This phenomenon has made digital marketing communications increasingly widespread lately. Almost all levels of society use the internet to find out the product they are looking for. For practitioners in the world of marketing, of course this is a bright way to be able to market the company's products more effectively through the internet. However, the problem is whether the marketing communications carried out have considered several important aspects such as the Symbolic Interaction aspect which is the essence of social life. It is undeniable that humans live based on symbols that have been recognized and their meanings agreed upon together. The diversity of meanings and interpretations of each person is sometimes a barrier in communication. The research method used is an exploratory case study research method. Data was collected by means of in-depth interviews with several credible sources. The purpose of this study is to find out how Symbolic Interaction plays a role in the marketing communication planning process carried out by a company. The results showed that Symbolic Interaction played a significant role in planning digital marketing communications, described through a brainstorming process, considering self-reflection through other people's views, the use of colors and symbolic logos.
\end{abstract}

Keywords: digital marketing, marketing communication, symbolic interactionism

\begin{abstract}
Abstrak
Perkembangan industri digital dalam satu dekade terakhir berujung pada pelaku usaha yang ikut terbawa arus digitalisasi dalam segala bidang usaha, mulai dari bidang makanan, pariwisata, transportasi, hingga jasa sekalipun. Fenomena ini yang menjadikan komunikasi pemasaran digital semakin marak akhir-akhir ini. Hampir seluruh lapisan masyarakat menggunakan internet untuk mencari tahu produk yang sedang dicari. Bagi praktisi dalam dunia pemasaran, tentu hal ini menjadi suatu jalan terang untuk dapat memasarkan produk perusahaan lebih efektif melalui internet. Namun yang menjadi permasalahan adalah apakah komunikasi pemasaran yang dilakukan apakah sudah mempertimbangkan beberapa aspek penting seperti aspek Interaksi Simbolik yang merupakan esensi daripada kehidupan bermasyarakat. Tak dapat dipungkiri bahwa manusia hidup berdasarkan simbol-simbol yang telah diakui dan disepakati makna nya secara bersama-sama. Keberagaman makna dan interpretasi tiap orang ini yang terkadang menjadi hambatan dalam komunikasi. Metode penelitian yang dilakukan adalah metode penelitian studi kasus eksploratoris. Pengumpulan data dilakukan dengan wawancara mendalam dengan beberapa narasumber yang kredibel. Tujuan penelitian ini adalah untuk mengetahui bagaimana Interaksi Simbolik berperan dalam proses perencanaan komunikasi pemasaran yang dilakukan oleh suatu perusahaan. Hasil
\end{abstract}


penelitian menunjukkan bahwa Interaksi Simbolik berperan signifikan dalam perencanaan komunikasi pemasaran digital, terdeskripsi melalui adanya proses brainstorming, mempertimbangkan refleksi diri melalui pandangan orang lain, penggunaan warna dan logo simbolis.

Kata Kunci: digital marketing, interaksi simbolik, komunikasi pemasaran

\section{Pendahuluan}

Komunikasi pemasaran yang dilakukan secara digital akhir-akhir ini begitu marak di dunia bisnis sehingga membuat seluruh pelaku bisnis mau tidak mau harus ikut beradaptasi. Kegiatan yang saat ini menjadi suatu senjata ampuh bagi perusahaan adalah kegiatan pemasaran digital yang dilakukan di media sosial seperti Instagram, Facebook, Tiktok, dan lain sebagainya. Pemilihan saluran komunikasi yang akan digunakan sebagai media pemasaran ini cukup penting. Berdasarkan informasi, peringkat nomor satu untuk media sosial paling populer yang pertama dipegang oleh Youtube, disusul oleh Whatsapp di peringkat kedua, dan Instagram mengejar di peringkat ketiga setelah berhasil menggeser mundur Facebook (Dahono, 2021).

Instagram mulai digandrungi oleh berbagai pelaku bisnis dikarenakan fitur nya yang beragam dan mudah untuk digunakan. Adapun beberapa fitur utama yang tersedia pada Instagram adalah sebagai berikut:

1. Stories, dengan adanya fitur ini pengguna dapat membagian cerita nya kepada seluruh pengikut akun, dapat berupa foto atau video.

2. Akun Bisnis, dengan adanya fitur ini pengguna dapat menggunakan akun Instagram nya sebagai akun bisnis yang dapat melihat statistik pengunjung pada akun tersebut. Fitur ini sangat memudahkan pelaku bisnis untuk melihat reaksi market mengenai bisnis mereka. Pada data statistik dapat dilihat berapa banyak yang berkunjung, berapa banyak yang melihat konten yang ada, hingga berapa banyak orang yang menyimpan foto di akun Instagram pengguna.

3. Reels, fitur ini merupakan fitur yang serupa dengan TikTok dan baru saja diluncurkan beberapa waktu yang lalu. Kepopuleran media berbagi foto dan video seperti TikTok membuat Instagram mau tidak mau harus ikut mengembangkan aplikasi mereka agar tetap dapat berjalan secepat dengan perkembangan arus digital. Dengan adanya fitur ini, pelaku bisnis dapat berkreasi dan membuat berbagai kreasi video dan membagikan nya di Instagram .

Dengan fitur-fitur utama ini, tidak heran bahwa Instagram dapat bersaing dan mengalahkan Facebook untuk keperluan pemasaran digital. Fitur-fitur ini nyatanya sangat membantu bagi pelaku usaha, terutama bagi pelaku usaha yang memiliki pasar dengan rentang remaja hingga dewasa.

Komunikasi pemasaran diharapkan dapat membantu perusahaan untuk meningkatkan penjualan/sales, namun kenyataan di lapangan masih banyak perusahaan yang tidak mendapatkan konversi sales atas komunikasi pemasaran yang dilakukan, setelah diteliti lebih dalam ternyata komunikasi pemasaran yang dilakukan gagal karena tidak melakukan riset, tidak sesuai kebiasaan pasar, dan lain-lain. Berbagai bidang usaha tidak luput dari kegiatan ini, salah satunya adalah perusahaan digital printing, yaitu PT Digital Suplai Indonesia. Perusahaan ini adalah perusahaan yang menjual mesin-mesin digital printing untuk keperluan percetakan. Sebagai perusahaan yang sebagian besar pasarnya adalah pasar perusahaan sehingga tipe bisnis 
mereka adalah Business to Business (B2B), peneliti ingin melihat bagaimana perencanaan komunikasi pemasaran yang mereka lakukan.

Industri percetakan digital masih mampu bertahan selama pandemi Covid-19 melanda Indonesia tahun 2020 silam. Hal ini disebabkan kegiatan periklanan yang tidak akan pernah terhenti dalam kehidupan manusia. Selain itu hampir seluruh bidang menggunakan media cetak untuk melakukan publikasi ataupun periklanan, mulai dari pemerintahan, sekolah, rumah sakit, perkantoran, dsb (Lestarini, 2021).

Manusia berkomunikasi satu sama lain dengan menggunakan simbol-simbol, baik disampaikan secara verbal maupun non-verbal, baik secara implisit maupun eksplisit. Simbol-simbol ini pada awalnya tidak memiliki makna sama sekali hingga manusia itu berinteraksi menggunakan simbol dan memberikan makna pada simbol itu sendiri. Makna tersebut tentu telah disetujui secara bersama-sama. Teori interaksi simbolik menjelaskan bahwa manusia memiliki interpretasi yang berbeda-beda akan sebuah simbol yang ada di hadapan mereka, kemudian teori ini berusaha untuk menjelaskan bahwa segala bentuk interaksi yang terjadi diantara manusia itu terjadi akibat adanya komunikasi (Nugroho, 2016).

Berdasarkan fenomena ini peneliti ingin meneliti lebih jauh lagi mengenai bagaimana peran interaksi simbolik dalam perencanaan komunikasi pemasaran yang dilakukan oleh suatu perusahaan.

\section{Metode Penelitian}

Penelitian ini menggunakan pendekatan penelitian kualitatif. Penelitian kualitatif adalah penelitian yang dilakukan dengan fokus utama untuk menafsirkan fenomena yang terjadi dan penelitian tersebut dilakukan melalui berbagai metode yang ada (Anggito \& Setiawan, 2018). Sedangkan untuk metode penelitian yang peneliti gunakan dalam penelitian ini adalah metode penelitian studi kasus eksploratoris. Studi kasus dilakukan dengan terperinci, mendetil, dan mendalam akan suatu peristiwa yang menjadi fokus daripada penelitian. Dengan penggunaan studi kasus eksploratoris peneliti berharap dapat menggambarkan peran interaksi simbolik dalam perencanaan komunikasi pemasaran secara utuh.

Subjek dalam penelitian ini adalah pihak-pihak yang menjadi narasumber dalam wawancara mendalam yang peneliti lakukan. Dalam menentukan subjek penelitian, peneliti memilih berdasarkan latar belakang yang relevan dengan tema penelitian, bekerja di perusahaan tersebut, menjadi pengikut dari akun Instagram @ digitalsuplaiindonesia, serta pernah melakukan pembelian di PT Digital Suplai Indonesia. Berdasarkan hal tersebut, peneliti menetapkan sebanyak sebanyak tujuh orang yang menjadi narasumber dalam penelitian ini, terbagi menjadi empat orang dalam perusahaan serta tiga orang dari luar perusahaan. Sedangkan yang menjadi objek dalam penelitian ini adalah peran Interaksi Simbolik dalam perencanaan komunikasi pemasaran digital.

Metode pengumpulan data yang peneliti gunakan dalam penelitian ini adalah dengan melakukan wawancara mendalam dengan para narasumber, melakukan studi kepustakaan, melakukan observasi secara langsung, dan dokumentasi guna mendukung kepentingan penelitian.

Pengolahan data peneliti lakukan dengan melakukan tiga tahapan yaitu mulai dari reduksi data untuk membuat hasil wawancara menjadi lebih terperinci dan detil, kemudian melakukan penyajian akan data yang telah direduksi agar peneliti dapat menarik kesimpulan pada akhir proses penelitian, dan yang terakhir adalah tahap 
penarikan kesimpulan, pada tahapan ini peneliti telah mampu menarik kesimpulan dan menggambarkannya secara deskriptif dan menjawab pertanyaan penelitian yang dilakukan.

\section{Hasil Temuan dan Diskusi}

PT Digital Suplai Indonesia adalah perusahaan yang bergerak di bidang distributor mesin digital printing berkualitas. Berdiri sejak tahun 2013 membuat perusahaan ini telah menjadi salah satu perusahaan digital printing yang berpengalaman. PT Digital Suplai Indonesia terletak di Komplek Industri Griya Idola blok G nomor 8, Jalan Raya Serang KM 12, Tangerang, Banten. Sejarah awal perusahaan ini terbentuk dikarenakan owner memiliki pengalaman yang cukup dalam di dunia printing, kemudian melihat peluang yang cukup besar di dunia percetakan khususnya digital. Hal ini yang menjadi latar belakang owner pada akhirnya memutuskan untuk melakukan impor akan mesin-mesin digital printing premium dan memasarkannya untuk pasar Indonesia.

Adapun visi dan misi dari PT Digital Suplai Indonesia adalah menjadi market leader dalam dunia percetakan di Indonesia yang menyuplai berbagai pilihan mesin digital printing berkualitas. Sedangkan misinya adalah: (1) Membangun perusahaan dengan integritas yang tinggi; (2) Mengembangkan sumber daya manusia yang berkualitas dan kompeten di bidang terkait; (3) Memberikan layanan after-sales yang memuaskan bagi konsumen.

Setelah melakukan penelitian dan wawancara dengan para narasumber, peneliti menemukan beberapa temuan, diantaranya adalah sebagai berikut:

\section{Peran Interaksi Simbolik}

PT. Digital Suplai Indonesia menerapkan penggunaan simbol signifikan hampir di seluruh kegiatan yang mereka lakukan, baik secara langsung maupun secara digital. Dalam kegiatan langsung contohnya adalah pembuatan invoice, dalam kegiatan digital adalah konten-konten di media sosial Instagram. Dalam kegiatankegiatan tersebut, perusahaan akan selalu menyisipkan logo perusahaan sebagai simbol signifikan yang telah memiliki makna bagi kebanyakan orang. Adapun logo yang menjadi simbol signifikan tersebut dapat dilihat pada Gambar.1

Gambar 1. Logo PT. Digital Suplai Indonesia
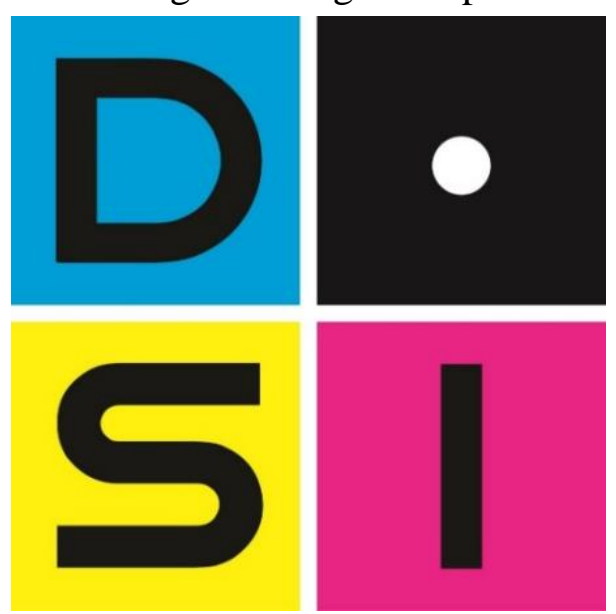

Sumber: Dokumentasi Pribadi 
Peneliti menemukan beberapa peran interaksi simbolik dalam perencanaan komunikasi pemasaran yang dilakukan oleh PT Digital Suplai Indonesia, diantaranya adalah sebagai berikut:

a. Significant Symbol

Simbol signifikan menjadi suatu hal penting bagi perusahaan, dalam hal ini yang menjadi simbol adalah logo perusahaan itu sendiri. Logo diibaratkan sebagai identitas bagi perusahaan sehingga tidak akan pernah dilupakan. Logo ini menjadi signifikan bagi perusahaan karena logo dibuat dan dirancang berdasarkan makna simbolis yang ingin disampaikan oleh perusahaan terhadap khalayak luas. Logo seperti yang terlihat pada Gambar.1 dibuat dengan empat warna dasar, yaitu biru, kuning, merah muda, dan hitam. Pemilihan warna dasar ini memiliki alasan yang sangat kuat, yaitu karena warna-warna tersebut merupakan warna dasar dalam dunia printing. Warna tersebut ialah warna Cyan, Magenta, Yellow, Key/Black (CMYK). Berdasarkan makna yang melekat pada warna-warna tersebut, maka akhirnya terbentuklah logo seperti yang dapat dilihat pada Gambar.1 dengan harapan masyarakat dapat langsung mengetahui dan memaknai perusahaan PT Digital Suplai Indonesia sebagai perusahaan yang bergerak di bidang digital printing.

b. Konsep Diri/Self

Konsep ini berperan penting dalam perencanaan komunikasi pemasaran karena dengan menggunakan konsep ini, komunikator yang menyampaikan pesan kepada komunikan terlebih dahulu berusaha memosisikan dirinya sebagai komunikan untuk melihat bagaimana perusahaan itu tampak di mata orang lain. Seseorang berkembang melalui proses yang rumit dan panjang dan berlangsung untuk waktu yang lama. "Diri" terbentuk akibat tanggapan orang lain, dalam konteks ini maka seorang digital marketer perlu melihat bagaimana akun yang dikelola dilihat atau ditanggapi oleh orang lain, tanggapan ini yang secara perlahan membentuk kepribadian dari akun tersebut. Dengan demikian maka harapan nya konten atau ide yang akan dikerjakan akan diterima dengan baik di masyarakat.

c. Particular Others

Dalam berinteraksi dengan banyak orang di kehidupan ini, setidaknya pasti ada orang yang memberikan banyak pengaruh ke dalam hidup seseorang. Peneliti menemukan bahwa senior atau atasan hampir sebagian besar selalu menjadi significant others bagi orang yang berada dibawahnya. Dengan demikian secara tidak langsung orang yang menjadi significant others secara simbolik telah menjadi panutan bagi orang-orang yang menganggap mereka adalah orang yang berpengaruh dalam hidup mereka.

\section{Perencanaan Komunikasi Pemasaran}

Perencanaan komunikasi pemasaran di PT Digital Suplai Indonesia khususnya pada bidang digital marketing di media sosial Instagram akan peneliti sampaikan berdasarkan kepada proses perencanaan komunikasi pemasaran yang dijabarkan sebelumnya pada (Pribadi, 2018), adapun proses tersebut adalah sebagai berikut:

a. Tujuan Bisnis

Hal pertama yang menjadi awal dasar pembentukan suatu perusahaan ialah menentukan apa yang menjadi tujuan bisnis perusahaan tersebut, dalam hal ini yang menjadi tujuan bisnis PT Digital Suplai Indonesia adalah menjadi market leader dalam bidang digital printing. 


\section{b. Strategi}

Strategi yang digunakan oleh perusahaan adalah dengan menjadi aktif pada media sosial dikarenakan perusahaan berusaha untuk melakukan penetrasi terhadap pasar ritel. Selain itu strategi yang digunakan dalam hubungan antar tim adalah dengan strategi komunikasi terbuka, dengan adanya komunikasi terbuka maka segala hambatan dan yang menjadi masalah akan lebih mudah terselesaikan dibandingkan dengan tidak adanya komunikasi di antara seluruh tim dalam perusahaan.

c. Taktis

Taktis yang digunakan oleh perusahaan adalah dengan berusaha untuk membuat konten menarik hingga menimbulkan rasa ingin tahu di benak calon konsumen. Contoh konten menarik ialah konten-konten infografis yang memberikan informasi baru bagi konsumen mengenai dunia percetakan.

d. Implementasi

Implementasi yang dilakukan adalah dengan memilih saluran komunikasi yang sesuai dengan target pasar, menyampaikan informasi dengan rinci dan detil, dan menerapkan sistem posting yang konsisten. Dalam tahap ini yang dipilih untuk menjadi saluran komunikasi pemasaran perusahaan ialah Instagram.

e. Monitoring

Dalam hal ini monitoring selalu ada pada perusahaan, setiap divisi selalu memiliki kepala divisi yang bertanggung jawab atas segala kegiatan yang dilakukan oleh divisi tersebut. Dengan adanya monitoring ini maka kegiatan yang dilakukan akan menjadi lebih terarah.

f. Evaluasi

Evaluasi di PT Digital Suplai Indonesia adalah suatu kegiatan yang tidak dapat dilewati dan diusahakan seluruh anggota tim harus ikut pada kegiatan ini. Hal ini disebabkan oleh perusahaan menganggap bahwa segala kegiatan yang dilakukan akan dapat dikoreksi apabila ada evaluasi di dalam nya, apabila setiap kegiatan dilakukan begitu saja tanpa adanya evaluasi maka perusahaan tidak akan berkembang karena tidak tahu letak kekurangan atau bahkan kesalahannya ada dimana, sehingga tidak akan terjadi perbaikan dan perkembangan bagi kemajuan perusahaan tersebut.

\section{Simpulan}

Berdasarkan penelitian yang peneliti lakukan, berikut adalah beberapa kesimpulan yang dapat peneliti sampaikan, diantaranya adalah sebagai berikut:

1. Peran Interaksi Simbolik dalam proses perencanaan komunikasi pemasaran digital sangat signifikan, terdeskripsi melalui adanya aktivitas brainstorming yang dilakukan dengan tujuan untuk meninjau bagaimana simbol yang digunakan oleh perusahaan nantinya akan dilihat oleh khalayak, penggunaan warna simbolis, serta mempertimbangkan bagaimana perusahaan terlihat melalui pandangan orang lain, pertimbangan ini yang akhirnya mempengaruhi tindakan-tindakan yang dilakukan oleh tim digital marketing di PT Digital Suplai Indonesia dalam melakukan komunikasi pemasaran digital melalui media sosial Instagram .

2. Interaksi Simbolik bermanfaat dalam membuat komunikasi pemasaran menjadi lebih efektif karena ditinjau dari segala sisi sehingga meminimalisir resiko negatif akibat konten yang dihasilkan. 
3. Proses perencanaan komunikasi pemasaran yang dilakukan oleh PT Digital Suplai Indonesia mulai dari ide hingga terbentuknya suatu konten diantaranya adalah dengan menentukan produk, menentukan pangsa pasar yang akan dituju, memilih media atau saluran komunikasi yang akan digunakan, perumusan ide atau konsep, melakukan eksekusi ide, dan yang terakhir adalah melakukan evaluasi terhadap kegiatan yang telah dilakukan. Proses perencanaan komunikasi pemasaran yang runut dan teratur menghasilkan sebuah sistem yang dapat dianalisis guna keperluan kemajuan perusahaan.

\section{Ucapan Terima Kasih}

Peneliti ingin mengucapkan terima kasih kepada Fakultas Ilmu Komunikasi Universitas Tarumanagara, narasumber, serta semua pihak yang turut membantu peneliti sehingga penelitian ini dapat diselesaikan.

\section{Daftar Pustaka}

Anggito, A., \& Setiawan, J. (2018). Metodologi Penelitian Kualitatif - Google Buku.

Dahono, Y. (2021). Data: Ini Media Sosial Paling Populer di Indonesia 2020-2021. https://www.beritasatu.com/digital/733355/data-ini-media-sosial-palingpopuler-di-indonesia-20202021

Lestarini, A. H. (2021). Makin Cuan, Bisnis Percetakan Digital Bertahan di Tengah Pandemi. https://www.medcom.id/ekonomi/entrepreneurship/ybJOy0jkmakin-cuan-bisnis-percetakan-digita 1-bertahan-di-tengah-pandemi

Nugroho, O. C. (2016). Interaksi Simbolik Dalam Komunikasi Budaya (Studi Analisis Fasilitas Publik Di Kabupaten Ponorogo). ARISTO, 3(1), 1. https://doi.org/10.24269/ARS.V3I1.7

Pribadi, M. A. (2018). Dinamika Perkembangan Perusahaan Periklanan Indonesia. http://repository.unpad.ac.id/frontdoor/index/index/docId/34431 